\title{
Dose- and time-dependent effects of $17 \beta$-oestradiol on insulin sensitivity in insulin-dependent tissues of rat: implications of IRS-1
}

\author{
C González, A Alonso, F Díaz and A M Patterson \\ Departamento de Biología Funcional (Fisiología), Facultad de Medicina, Universidad de Oviedo, C/Julián Clavería s/n 33006 Oviedo, Spain \\ (Requests for offprints should be addressed to C González; Email: tinog@correo.uniovi.es) \\ (C González and A Alonso contributed equally to this work)
}

\begin{abstract}
Numerous studies have suggested that ovarian hormones are able to modulate insulin sensitivity, but their exact role remains unclear. We have investigated whether different doses of $17 \beta$-oestradiol mediate changes in insulin sensitivity and if these changes could be related to modifications of insulin receptor substrate-1 (IRS-1). Female rats were ovariectomized and later separated into three groups: untreated; treated with a dose of $17 \beta$-oestradiol sufficient to reproduce gestational plasma concentrations of $17 \beta$-oestradiol (group E); and treated with a dose 100 times greater than that given to group E (group E2). A euglycaemic-hyperinsulinaemic clamp was used to measure insulin sensitivity. Changes in IRS-1 were analysed by Western blotting and RT-PCR assays. In group $\mathrm{E}$ we found a decrease in insulin sensitivity between
\end{abstract}

days 11 and 16 of treatment as in late gestation, whereas in the untreated group and group E2, development of insulin resistance was observed throughout the treatment. In contrast, whereas in group E2 insulin resistance throughout the hormonal treatment was related to diminished expression and phosphorylation of IRS-1, in group E the decrease in insulin sensitivity between days 11 and 16 of treatment was not related to a decrease in IRS-1 expression. Our results suggest that the effects of oestradiol on insulin sensitivity were dose-dependent and that the insulin resistance associated with a high dose of $17 \beta$-oestradiol was related to downregulation of IRS- 1 expression.

Journal of Endocrinology (2003) 176, 367-379

\section{Introduction}

Insulin resistance can be defined as a complex nutritionalmetabolic state characterized by lower sensitivity of target tissues (liver, skeletal muscle and adipose tissue) to the physiological effects of insulin (Kaaks \& Lukanova 2001). Thus insulin resistance is considered as a common aetiological factor for the individual components of the metabolic syndrome, comprising hypertension, dyslipidaemia with or without hyperglycaemia, and abnormalities in the homeostatic system (Writing Group for the PEPI Trial 1995, Fagan \& Deedwania 1998). Individuals with this syndrome are at high risk for cardiovascular disease and type II (non-insulin-dependent) diabetes mellitus (NIDDM) (DeFronzo \& Ferrannini 1991, Reaven 1993).

Various clinical observations and experimental data suggest that insulin and sex hormones interact (Kumagai et al. 1993, Polderman et al. 1994). Thus the low levels of female sex steroids associated with the menopause (natural or surgical) are related to a decrease in whole-body insulin-mediated glucose uptake. The cellular mechanism behind this insulin resistance and the role of low levels of female sex steroids are not yet fully understood (Rincón et al. 1996). Many studies have found that oestrogen replacement therapy seems to improve insulin sensitivity in postmenopausal women (Godsland 1996, Colacurci et al. 1998, Karjalainen et al. 2001). However, the effects of oestrogen replacement therapy seem to be different depending on the dose, route and type of oestrogen utilized. In this respect, high doses of oral oestrogens $(1.25 \mathrm{mg} /$ day $)$ have been reported to cause a deterioration in, and low doses $(0.625 \mathrm{mg} /$ day $)$ to exert no or even beneficial effects on insulin-glucose metabolism (Cagnacci et al. 1992, Lindheim et al. 1993). However, both a low dose $(0.05 \mathrm{mg} /$ day $)$ and a high dose $(1 \mathrm{mg} /$ day $)$ of transdermal oestradiol improved insulin sensitivity (Lindheim et al. 1994), suggesting that the adverse effect of a high oral dose could be explained by first-pass metabolism in the liver (Krauss et al. 1988, Cagnacci et al. 1992). In women with NIDDM, the changes that accompany menopause may further diminish glycaemic control and insulin sensitivity (Ferrara et al. 2001). The beneficial effects on insulin sensitivity conferred by low-dose oestradiol replacement therapy in healthy postmenopausal women could be a source of particular benefit to diabetic postmenopausal women, some authors (Andersson et al. 
1997, Brussard et al. 1997) suggesting that low doses of oestradiol improve glycaemic control in these women. Furthermore, the predominant mechanism for these improvements seems to be an enhancing effect of oestradiol on insulin sensitivity in the liver (Sattar 1998).

An early event in insulin action, after receptor binding, is the activation of tyrosine kinase activity in the cytosolic domain of the receptor (Goldfine 1987). Insulin receptor substrate-1 (IRS-1) is a major endogenous substrate of the insulin receptor kinase and undergoes tyrosine phosphorylation upon insulin stimulation, after which it serves as a docking protein for a number of Src homology 2 domain-containing proteins such as Grb2, Syp, Nck and the two isoforms of the regulatory subunit of phosphatidylinositol 3-kinase (PI3K) (White \& Kahn 1994, Virkamaki et al. 1999). Although IRS-1 appears to have no catalytic function, it may act as a docking protein, bringing various component proteins of the insulin signalling pathway into proximity and forming a multifactorial signalling complex (Sun et al. 1992, Water \& Pessin 1996). These interactions are essential tools for the transmission and compartmentalization of the insulin signal from the receptor to the final cellular events such as stimulating glucose uptake, activating glycogen or protein synthesis, and initiating specific gene transcription (Virkamaki et al. 1999).

The classical mechanism of oestradiol action involves an intracellular receptor, which upon hormone binding assumes an activated state. This hormone-receptor complex is a transcriptionally active protein that is able to modulate gene expression (Beato 1989). However, the molecular mechanism responsible for the relationship between oestradiol and insulin sensitivity remains unclear. In most cases, investigations carried out in vitro have shown that oestradiol can increase the expression and phosphorylation of IRS-1 in human breast cancer cells (Lee et al. 1999, Molloy et al. 2000) or that oestradiol can decrease insulin-stimulated glucose transport by diminishing the concentrations of IRS-1 (Collison et al. 2001) in 3T3-L1 adipocytes. However, in some in vivo experiments, glucose metabolism in peripheral tissues was believed to be regulated in manner different from that in the liver (Dunaif et al. 1992, Huang et al. 1996). We consider it very difficult to reconcile these findings with whole-body metabolism. To our knowledge, there are no reports on the role of oestradiol in the modulation of the insulin signalling cascade on the principal insulin-sensitive tissues (liver, skeletal muscle and adipose tissue). More specifically, the possible direct action of oestradiol on the IRS-1 gene and protein regulation in in vivo studies is unknown.

In this work, we have investigated whether two different doses of $17 \beta$-oestradiol mediate changes in insulin sensitivity in ovariectomized rats, and whether these changes could be related to modifications in the amount of IRS-1, phosphorylation of this protein, or expression of the IRS-1 gene in the principal insulin-sensitive tissues: liver, skeletal muscle and adipose tissue.

\section{Materials and Methods}

\section{Animals}

We studied 12-week-old virgin female Wistar rats (from the University of Oviedo animal house) weighing 250$280 \mathrm{~g}$ and kept under standard conditions of temperature $\left(23 \pm 3{ }^{\circ} \mathrm{C}\right)$ and humidity $(65 \pm 1 \%)$, and a regular lighting schedule of $12 \mathrm{~h}$ light: $12 \mathrm{~h}$ darkness (lights on 0800$2000 \mathrm{~h}$ ). The animals were fed a standard diet (Panlab A04) and had free access to water. All experimental manipulations were performed between $0930 \mathrm{~h}$ and $1230 \mathrm{~h}$. The experiments were carried out in accordance with principles of laboratory animal care.

\section{Experimental design}

Three days before the hormonal treatment was initiated (day -7 ), the rats were ovariectomized through a midline incision under light ether anaesthesia. Ovariectomized rats were separated randomly into three groups: untreated group $(\mathrm{V})$, group $\mathrm{E}$ and group E2, and housed individually throughout the experiment.

After surgery, ovariectomized rats were allowed 3 days to recover from the stress of surgery and to allow their hormone levels to decrease. From day -4 the rats were injected subcutaneously, every $12 \mathrm{~h}(0900 \mathrm{~h}$ and $2100 \mathrm{~h})$ for 20 days, with $0 \cdot 1 \mathrm{ml}$ of a suspension of $17 \beta$-oestradiol (Sigma Chemical Co., St Louis, Missouri, USA) in olive oil/ethanol $(3: 2 \mathrm{v} / \mathrm{v})$. The control (untreated) group were injected with vehicle (olive oil/ethanol 3:2 v/v) in parallel. In group E, different doses of $17 \beta$-oestradiol were injected (González et al. 1998, 2002b) in order to simulate the plasma concentrations that we observed in normal pregnant rats (González et al. 1997). The doses of $17 \beta-$ oestradiol injected in group E2 were 100 times those injected in group E.

The hormonal treatment was applied according to the schedule shown in Fig. 1.

The three groups were divided randomly into three subgroups of six animals each, named group 6, group 11 and group 16 according to the day of the experimental procedure on which the animals were killed. These days were selected because changes have been found in sensitivity to the action of insulin during pregnancy in the Wistar rat (González et al. 1997).

\section{Euglycaemic insulin clamp}

Clamp experiments were performed in anaesthetized rats by a procedure described previously (González et al. 2000). Before the clamp began, and in order to determine basal 


\section{Ovariectomy}

$$
\downarrow
$$

\begin{tabular}{|c|c|c|c|c|c|c|c|c|c|c|c|c|c|}
\hline DAYS & $\begin{array}{ll}-7 & -6\end{array}$ & -5 & -4 & -3 & -2 & -1 & 0 & 1 & 2 & 3 & 4 & 5 & 6 \\
\hline$[\mathbf{E}]$ & - . & . & $\mathbf{E A}$ & EA & $\mathbf{E A}$ & $\mathbf{E A}$ & EA & EA & $\mathbf{E A}$ & $\mathbf{E A}$ & $\mathbf{E A}$ & $\mathbf{E A}$ & EB \\
\hline [E2] & - & $\cdot$ & E2A & E2A & E2A & E2A & E2A & E2A & E2A & E2A & E2A & E2A & E2B \\
\hline & DAYS & & 7 & 8 & 9 & 10 & $11^{*}$ & 12 & 13 & 14 & 15 & $16^{*}$ & \\
\hline & {$[\mathbf{E}]$} & & EB & EB & EB & EB & EA & EA & EA & EA & EA & & \\
\hline & [E2] & & E2B & E2B & E2B & $\mathrm{E} 2 \mathrm{~B}$ & E2A & E2A & E2A & $\mathbf{E} 2 \mathrm{~A}$ & E2A & & \\
\hline
\end{tabular}

\section{$\mathrm{EA}=0.006 \mathrm{mM} ; \mathrm{EB}=0.003 \mathrm{mM} ; \mathrm{E} 2 \mathrm{~A}=0.6 \mathrm{mM} ; \mathrm{E} 2 \mathrm{~B}=0.3 \mathrm{mM}$}

Figure 1 Schedule for hormonal treatment with $17 \beta$-oestradiol. *Day on which animals were killed for study. $[\mathrm{E}]$, oestradiol concentration.

insulin concentration, a blood sample $(1 \mathrm{ml})$ was collected from the jugular vein into heparinized tubes and centrifuged at 3000 r.p.m. for $20 \mathrm{~min}$ at $4{ }^{\circ} \mathrm{C}$, then plasma was immediately drawn off and stored frozen at $-20{ }^{\circ} \mathrm{C}$ until required for assay. A blood sample for the determination of basal blood glucose was collected from the tail. Plasma glucose was measured using an Accutrend System (Accutrend Alpha, Roche Diagnostic S.L., Barcelona, Spain).

After the clamp study, blood samples $(4 \mathrm{ml})$ for the determination of final insulin and $17 \beta$-oestradiol plasma concentrations were collected from the jugular vein into heparinized tubes, centrifuged at 3000 r.p.m. for $20 \mathrm{~min}$ at $4{ }^{\circ} \mathrm{C}$ and plasma immediately drawn off and stored frozen at $-20{ }^{\circ} \mathrm{C}$ until required for assay. The total volume of blood taken from each animal was 5.5-6.5 ml. Plasma insulin was measured by RIA using a kit (DGR Instruments $\mathrm{GmbH}$, Marburg, Germany) for rat insulin. The sensitivity of the assay was $0.1 \mathrm{ng} / \mathrm{ml}$, and the intra-assay coefficient of variation was $9 \cdot 32 \%$. The sample was assayed in duplicate. Plasma $17 \beta$-oestradiol was measured by RIA using Immuchen kits (ICN Biomedicals Inc., Orangeburg, NY, USA). The assay sensitivity was $10 \mathrm{pg} / \mathrm{ml}$, and the intra-assay coefficient of variation was $12 \cdot 26 \%$. All samples were measured on the same day. Finally, samples of different tissues were collected and immediately frozen in liquid nitrogen for future experiments and animals were killed by bleeding.

\section{Analysis of RNA by semiquantitative RT-PCR}

The RT-PCR, optimized for semiquantitative detection, was used to analyse overall levels of expression of IRS-1 mRNA in each individual animal of each different experimental group. Total RNA from the liver, skeletal muscle (flexor digitorum superficialis, extensor digitorum longus, soleus and extensor digitorum lateralis) and retroperito- neal adipose tissue samples of each individual animal were isolated by the guanidinium thiocyanate-phenolchloroform extraction method (Chomczynski \& Sacchi 1987) and treated with RNase-free DNase I (Amersham Pharmacia Biotech) in order to remove genomic DNA. For amplification of the targets we used the following oligonucleotides deduced from cloned rat IRS-1 (Gosbell et al. 2000): 5'-CCG GAA TTC GCC AAT CTT CAT CCA GTT GCT and 5'-CCC AAG CCT CAT CGT GAA GAA GGC ATA GGG. It is noteworthy that this primer pair was designed to amplify a $350 \mathrm{bp}$ fragment of rat IRS-1 cDNA. In addition, in order to provide an appropriate internal control, coamplification of a $540 \mathrm{bp}$ fragment of the $\beta$-actin mRNA was carried out in each sample using the following oligonucleotides deduced from cloned rat actin: 5'-CCG GAA TTC CGT GGG CCG CCC TAG GCA and 5'-CGC GGA TCC TTT AAT GTC AGG GAC GAT.

For amplification of the target, RT and PCR were run in two separate steps. Furthermore, to enable appropriate amplification in the exponential phase for each target, PCR amplifications of IRS- 1 and $\beta$-actin were carried out in separate reactions with a different number of cycles but using similar amounts of the corresponding cDNA templates, generated in single RT reactions. Briefly, equal amounts of total RNA $(5 \mu \mathrm{g})$ were heat-denatured and reverse-transcribed by incubation at $42{ }^{\circ} \mathrm{C}$ for $45 \mathrm{~min}$ using an RNA PCR Core Kit (Perkin Elmer Corp., Branchburg, NJ, USA) in a final volume of $30 \mu \mathrm{l}$. The reactions were terminated by heating at $99{ }^{\circ} \mathrm{C}$ for $5 \mathrm{~min}$ and finally at $4{ }^{\circ} \mathrm{C}$ for $5 \mathrm{~min}$. For semiquantitative PCR, $10 \mu \mathrm{l}$ aliquots of the cDNA samples (equivalent to $650 \mathrm{ng}$ total RNA input) were amplified using an RNA PCR Core Kit (Perkin Elmer Corp.) and the appropriate primer pairs. The number of cycles was optimized to ensure amplification in the exponential phase of PCR. Finally, we used 30 cycles of PCR amplifications to detect the IRS-1 
mRNA in adipose tissue and 28 cycles for liver and skeletal muscle. Conditions for the amplification were $30 \mathrm{~s}$ at $94{ }^{\circ} \mathrm{C}, 30 \mathrm{~s}$ at $55^{\circ} \mathrm{C}$ and $60 \mathrm{~s}$ at $72{ }^{\circ} \mathrm{C}$. Also, we used 30 cycles of PCR amplifications to detect $\beta$-actin mRNA in all tissues. Conditions for the amplification were $15 \mathrm{~s}$ at $94{ }^{\circ} \mathrm{C}, 15 \mathrm{~s}$ at $55^{\circ} \mathrm{C}$ and $45 \mathrm{~s}$ at $72{ }^{\circ} \mathrm{C}$.

The cDNA fragments generated were resolved in $0.8 \%$ agarose gel containing ethidium bromide $(0 \cdot 1 \mu \mathrm{g} / \mathrm{ml})$ and visualized and photographed with u.v. transillumination, their molecular sizes being determined by comparison

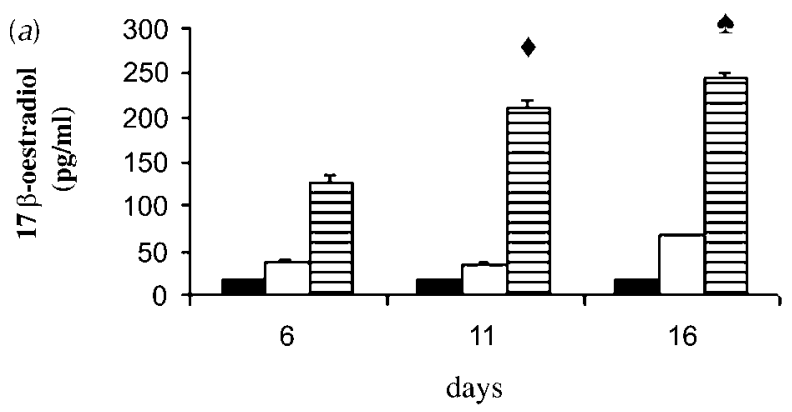

$\begin{array}{llll}\text { Intraday } & \text { E2 vs V, E } & \text { E2 vs V, E } & \text { E2 vs V, E } \\ \text { Comparison } & \text { Evs V } & \text { Evs V } & \text { E vs V }\end{array}$

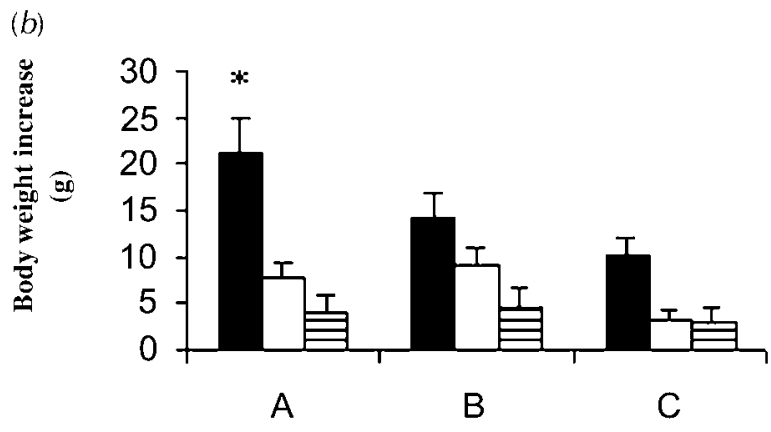

$\underset{\text { Comparison }}{\text { Intraday }} \quad$ V vs E, E2 $\quad$ V vs E2 $\quad$ V vs E, E2

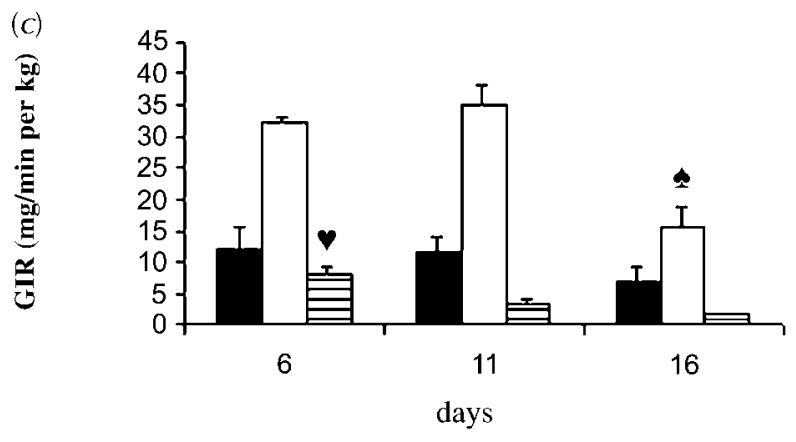

$\begin{array}{llll}\text { Intraday } & \text { E vs V, E2 } & \begin{array}{l}\text { E vs V, E2 } \\ \text { Comparison }\end{array} & \text { V vs E2 }\end{array}$

with size markers run together with the cDNA products. Specificity of PCR products was confirmed by digestion with specific restriction endonuclease (Taq I, MBI Fermentas Inc., Amherst, NY, USA). For quantitative evaluation, absolute optical densities of RT-PCR signals were obtained by densitometric scanning using an image analysis system (NIH Image 1.57 software). IRS-1 mRNA is expressed as a ratio: mRNA IRS-1: $\beta$-actin mRNA. Moreover, in order to ensure that equal inputs of RNA were added to RT-PCR reactions, only samples yielding roughly similar absolute optical density values for $\beta$-actin bands were considered for further analysis. In addition, to minimize potential RT-PCR artefacts due to inherent reaction variability, all data points were repeated at least three times for each sample, using independent RNA samples. Finally, in all assays, liquid controls and reactions without $\mathrm{RT}$ were included, yielding negative amplifications.

\section{Immunoprecipitation and Western blotting}

The samples of liver, skeletal muscle and adipose tissue of each animal were washed with ice-cold PBS and homogenized immediately in $3 \mathrm{ml}$ lysis buffer $(50 \mathrm{mM}$ Tris$\mathrm{HCl} \mathrm{pH} 7 \cdot 5,150 \mathrm{mM} \mathrm{NaCl}, 1 \%$ Nonidet P40 Roche Diagnostics, $0 \cdot 05 \%$ sodium deoxycholate, $0 \cdot 1 \%$ orthovanadate $1 \mathrm{M}$ ) at $4{ }^{\circ} \mathrm{C}$ using a Polytron (PT-MR-3000, Kinematica AG, Lucerne, Switzerland) operated at maximum speed for $30 \mathrm{~s}$. The extracts from each individual animal were centrifuged at $12000 \mathrm{~g}$ at $4{ }^{\circ} \mathrm{C}$ for $10 \mathrm{~min}$ in order to remove insoluble material. After centrifugation, the protein content was assayed by the Bradford dyebinding method (Bradford 1976) using BioRad reagents and BSA as standard. To ensure that the proteins were in a linear range of detection, preliminary experiments were conducted to determine that the amount of homogenate protein load was within a range that resulted in a proportionate change in signal intensity as the amount of protein loaded was varied. The aqueous fraction containing $250 \mu \mathrm{g}$ protein for liver and muscle and $150 \mu \mathrm{g}$ for adipose tissue was used for immunoprecipitation with $0 \cdot 25 \mu \mathrm{g}$ polyclonal

Figure 2 (a) Plasma concentrations of $17 \beta$-oestradiol in ovariectomized rats $(\mathrm{V})$ and rats treated with different doses of $17 \beta$-oestradiol (E, E2). (b) Comparison of increase in body weight in a control (vehicle-treated) group $(\mathrm{V})$ and in rats treated with different doses of oestradiol (E, E2). A, B, C: changes in body weight from day 0 to 6 , day 6 to 11 and day 11 to 16 respectively. (C) Comparison of glucose infusion rates in ovariectomized rats treated with vehicle $(\mathrm{V})$ or with different doses of oestradiol (E, E2). The rate of infusion of glucose was assessed as the mean values from 40 to 60 min during euglycaemichyperinsulinaemic clamp experiments. Values are means \pm S.E.M. for six animals. Solid bar, vehicle-treated group (V); open bar, group E; striped bar, group E2. Significant differences between treatment groups $(P \leqslant 0 \cdot 05)$ are listed for each experimental time point (intraday comparisons). Significant differences within treatment groups: ^ 16 vs 6,$11 ;{ }^{\bullet} 6$ vs 11,$16 ; " 11$ vs $16 ;{ }^{*} \mathrm{~A}$ vs $\mathrm{C}$. 
Table 1 Fasting blood glucose, fasting serum insulin and serum insulin after clamp experiment in rats treated with vehicle $(V)$ or with different doses of oestradiol (E, E2) on days 6, 11 and 16 of the experiment

\begin{tabular}{|c|c|c|c|c|}
\hline & Day 6 & Day 11 & Day 16 & $\begin{array}{l}\text { Significant } \\
\text { differences }\end{array}$ \\
\hline \multicolumn{5}{|c|}{ Fasting blood glucose (mg/dl) } \\
\hline $\mathrm{V}$ & $108 \cdot 77 \pm 4 \cdot 01$ & $110 \cdot 00 \pm 3 \cdot 00$ & $113 \cdot 16 \pm 2 \cdot 38$ & \\
\hline $\mathrm{E}$ & $118 \cdot 50 \pm 5 \cdot 31$ & $108 \cdot 33 \pm 4 \cdot 69$ & $117 \cdot 51 \pm 4 \cdot 44$ & \\
\hline E2 & $122 \cdot 00 \pm 5 \cdot 68$ & $120 \cdot 12 \pm 5 \cdot 39$ & $116 \cdot 71 \pm 6 \cdot 79$ & \\
\hline \multicolumn{5}{|c|}{ Fasting serum insulin $(\mathrm{ng} / \mathrm{ml})$} \\
\hline $\mathrm{V}$ & $0.67 \pm 0.02$ & $0 \cdot 73 \pm 0 \cdot 02$ & $0 \cdot 85 \pm 0 \cdot 03$ & 16 vs 6,11 \\
\hline $\mathrm{E}$ & $1.03 \pm 0.03$ & $0.52 \pm 0.01$ & $0 \cdot 74 \pm 0 \cdot 02$ & 16 vs 6,$11 ; 6$ vs 11 \\
\hline $\mathrm{E} 2$ & $1 \cdot 60 \pm 0.05$ & $1 \cdot 01 \pm 0.03$ & $1 \cdot 33 \pm 0 \cdot 024$ & 16 vs 6,$11 ; 6$ vs 11 \\
\hline Comparison & $\begin{array}{c}\text { E2 vs } V, E \\
E \text { vs } V\end{array}$ & $\begin{array}{c}\text { E2 vs } V, E \\
E \text { vs } V\end{array}$ & $\begin{array}{l}\text { E2 vs } V, E \\
\text { E vs } V\end{array}$ & \\
\hline \multicolumn{5}{|c|}{ Serum insulin post clamp ${ }^{\dagger}(\mathrm{ng} / \mathrm{ml})$} \\
\hline V & $2 \cdot 15 \pm 0 \cdot 55$ & $7 \cdot 45 \pm 1 \cdot 97$ & $11 \cdot 54 \pm 3 \cdot 78$ & 16 vs 6,$11 ; 11$ vs 6 \\
\hline $\mathrm{E}$ & $5 \cdot 18 \pm 1 \cdot 25$ & $3 \cdot 85 \pm 0 \cdot 78$ & $1.99 \pm 0.37$ & 6 vs 11,$16 ; 11$ vs 16 \\
\hline $\mathrm{E} 2$ & $2 \cdot 84 \pm 0.55$ & $1 \cdot 54 \pm 0 \cdot 32$ & $2 \cdot 41 \pm 0 \cdot 73$ & 6 vs 11,$16 ; 11$ vs 16 \\
\hline Comparison & $\begin{array}{l}\text { E2 vs } V, E \\
E \text { vs } V\end{array}$ & $\begin{array}{l}V \text { vs } E, E 2 \\
E \text { vs E2 }\end{array}$ & V vs E, E2 & \\
\hline
\end{tabular}

Values are means \pm S.E.M. for six animals per group. ${ }^{\dagger}$ After clamp experiments. Only significant differences are shown.

antibody against IRS-1 (sc-559; Santa Cruz Biotech., Inc. Santa Cruz, CA, USA). The immune-complexes were precipitated with protein G-agarose beads (Roche Diagnostics) overnight at $4{ }^{\circ} \mathrm{C}$ in a rocking platform and were washed several times in wash buffer $(50 \mathrm{mM}$ Tris$\mathrm{HCl} \mathrm{pH} 7 \cdot 5,500 \mathrm{mM} \mathrm{NaCl}, 0 \cdot 1 \%$ Nonidet P40, 0.05\% sodium deoxycholate, $0 \cdot 1 \%$ orthovanadate $1 \mathrm{M}$ ). After washing, the pellet was suspended in protein loading buffer $(250 \mathrm{mM}$ Tris- $\mathrm{HCl}$ pH $6 \cdot 8, \quad 8 \%$ SDS, $8 \mathrm{mM}$ EDTA, 35\% glycerol, 2.5\% $\beta$-mercaptoethanol, bromophenol blue) and heated in a boiling water bath for $5 \mathrm{~min}$. Efficacy of each immunoprecipitation was $100 \%$, as confirmed by Western blot analysis of a second round of immunoprecipitation, which yielded no detectable IRS-1 protein.

For total extract, duplicate similar-sized aliquots were subjected to SDS-PAGE (7\% Tris-Acri-Bis) in a BioRad miniature slab gel apparatus. The prestained molecular mass standards used were myosin $(218 \mathrm{kDa})$, b-galactosidase $(126 \mathrm{kDa})$, BSA $(90 \mathrm{kDa})$, carbonic anhydrase $(43.5 \mathrm{kDa})$, soybean trypsin inhibitor $(33.9 \mathrm{kDa})$, lysozyme $(17 \cdot 4 \mathrm{kDa})$ and aprotinin $(7 \cdot 6 \mathrm{kDa})$ (BioRad). Electrotransfer of proteins from the gel to nitrocellulose membranes (Hybond-ECL, Amersham Pharmacia Biotech) was performed for $60 \mathrm{~min}$ at $50 \mathrm{~V}$ (constant) in a BioRad miniature transfer apparatus (MiniProtean) as described by Towbin et al. (1979). Adult rat skeletal muscle protein was used as a positive control for IRS-1 protein.

Non-specific binding of protein to the nitrocellulose membranes was reduced by preincubating the filter for $2 \mathrm{~h}$ at room temperature in blocking buffer (TNT, 7\%
BSA), and probing with a 1:75000 dilution of antiphosphotyrosine antibody (sc-7020, Santa Cruz Biotech., Inc.) conjugated to horseradish peroxidase for $1 \mathrm{~h}$ at room temperature, diluted in blocking buffer. The membranes were rinsed several times with blocking buffer without BSA and proteins were detected with enhanced chemiluminescence (ECL) reagent (Amersham Pharmacia Biotech) according to the manufacturer's instructions and using autoluminography on Kodak X-Omat film.

Later, the membranes were incubated for $40 \mathrm{~min}$ in stripping buffer $(50 \mathrm{ml}$ Tris- $\mathrm{HCl} 62.5 \mathrm{mM} \mathrm{pH} 6 \cdot 8,1 \mathrm{~g}$ SDS, $0.34 \mathrm{ml} \beta$-mercaptoethanol) at $55^{\circ} \mathrm{C}$. After this, another Western blot analysis was performed (WesternLight, Chemiluminescent Detection System, Tropix, Inc., Bedford, MA, USA) using a 1:5000 dilution of polyclonal antibody against IRS-1 as the primary antibody, followed by alkaline-phosphatase-conjugated anti-rabbit $\operatorname{IgG}$ antibody (Tropix, Inc.) for detection. Finally, the proteins were detected by autoluminography on Kodak $\mathrm{X}$-Omat film.

Western blots were quantified using a digital scanner (Nikon AX-110) and NIH Image 1.57 software.

\section{Statistics}

Data are expressed as means \pm S.E.M. Within-group comparisons for the period of hormonal treatment were made using analysis of variance (ANOVA) or Kruskal-Wallis one-way ANOVA, and the Student-Newman-Keuls test or Mann-Whitney U-Wilcoxon rank sum W test. A value of $P \leq 0.05$ was considered significant. Statistical analysis was performed using SPSS for Windows version 6.01. 
(a)
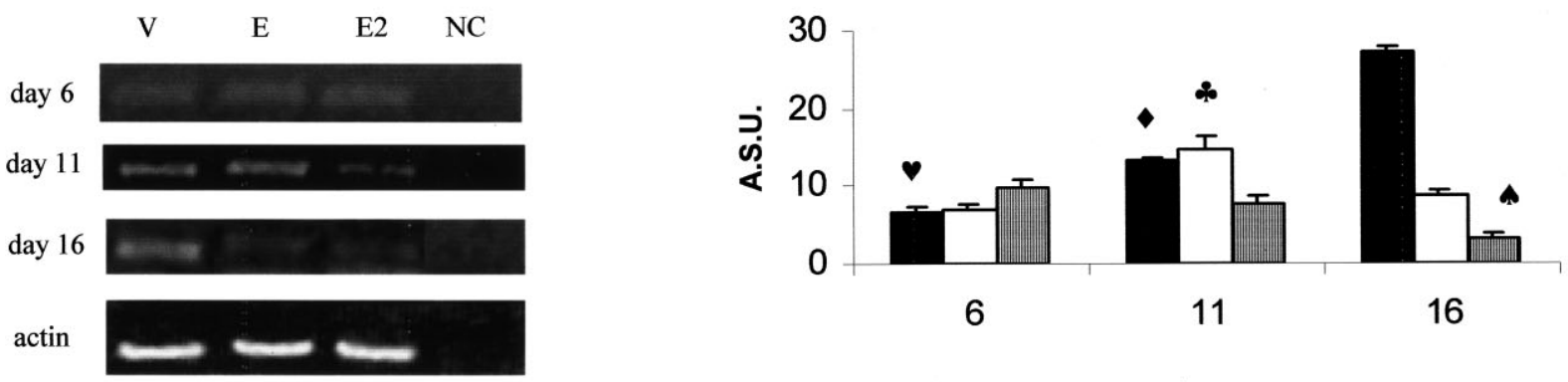

Intraday comparison $\quad$ E2 vs V, E $\quad$ V vs E, E2

(b)
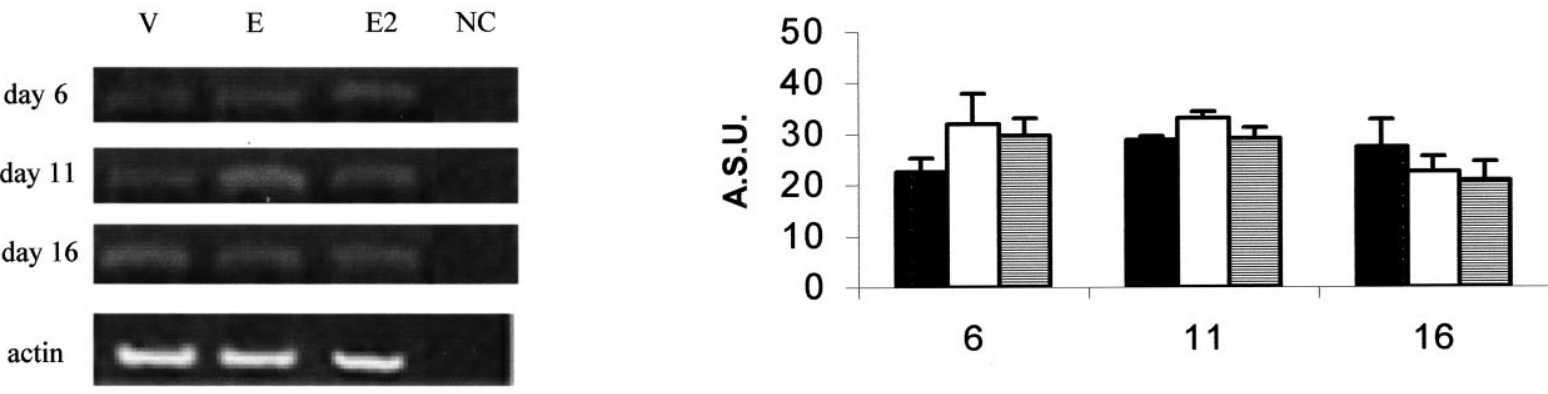

\section{days}

(c)
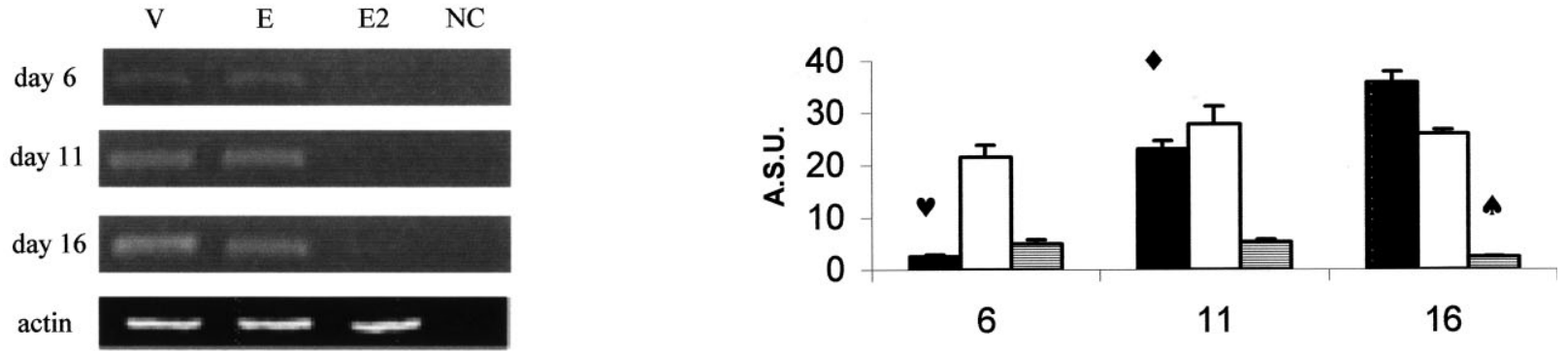

days

- V DE GE2

Intraday comparison

E vs V,E2

E2 vs V,E

V vs E, E2

Evs E2

Figure 3 Representative experiments for expression analysis of IRS-1 in (a) liver, (b) skeletal muscle, and (c) adipose tissue in control rats (solid bars, V) and oestradiol-treated rats (open bars, group E; shaded bars, group E2) at days 6, 11 and 16 of treatment. Left: RT-PCR was performed on $5 \mu \mathrm{g}$ RNA from the samples. A $350 \mathrm{bp}$ fragment corresponding to a segment of IRS-1 was amplified in a volume of $100 \mu \mathrm{l}$, and $10 \mu \mathrm{l}$ of the reaction was separated on a $0 \cdot 8 \%$ agarose gel. A $540 \mathrm{bp}$ fragment corresponding to a $\beta$-actin was amplified as an internal control. Reactions without the RNA sample were performed as negative controls (lane NC). Right: Relative abundance of IRS-1 mRNA. The results were corrected by the endogenous levels of $\beta$-actin mRNA. Data are expressed as means \pm S.E.M. A.S.U., arbitrary scanning units. Significant differences between treatment groups are listed for each experimental time point (intraday comparison). Within the treatment groups, the following significant differences $(P<0 \cdot 05)$ were identified over time: ${ }^{\bullet} 6$ vs 11,$16 ;{ }^{\star} 11$ vs $16 ; * 11$ vs 6,16 ; ${ }^{\star} 16$ vs 6,11 . 


\section{Results}

Plasma concentrations of $17 \beta$-oestradiol are shown in Fig. $2 a$. The concentrations in group $\mathrm{E}$ were similar to those in normal pregnant rats at 5, 10 and 15 days of pregnancy (González et al. 1997). In this group, we found similar values at 6 and 11 days of treatment and a significant increase between 6-16 and 11-16 days of treatment. The concentrations in group E2 were significantly greater than those in group $\mathrm{E}$ and the untreated group. The plasma concentrations of $17 \beta$-oestradiol were dependent on the solution injected, thus we observed that the plasma concentration of $17 \beta$-oestradiol increased as follows: at day 6 , $238 \%$ in group E compared with the untreated group, and $787 \%$ in group E2 compared with the untreated group; at day 11, 188\% in group E compared with the untreated group, and $1145 \%$ in group E2 compared with the untreated group; at day 16, 401\% in group E compared with the untreated group, and $1463 \%$ in group E2 compared with the untreated group.

Comparisons of increase in body weight can be seen in Fig. 2b. The increase in body weight was significantly greater on days $0-6$ of the experimental period in the untreated group compared with days 11-16. No differences were noted in the other groups. On days 0-6 (Fig. $2 b, \mathrm{~A}$ ), the increase in body weight was significantly greater in the the untreated group than in the other groups. On days 6-11 (Fig. 2b, B) the increase in body weight was significantly greater in the untreated group than in group E2. On days 11-16 (Fig. 2b, C) the increase in body weight was significantly greater in the untreated group than in groups E and E2.

To investigate insulin resistance in the rats at different days of the hormonal treatment, glucose clamp experiments were carried out under euglycaemic and hyperinsulinaemic conditions. Figure $2 c$ shows the comparison of glucose infusion rates in different groups of rats treated with different doses of $17 \beta$-oestradiol. At days 6, 11 and 16 , the insulin sensitivity was significantly greater in group $\mathrm{E}$ than in the other groups. Studying the effect of the hormonal treatment, we were able to observe that in the untreated group the insulin sensitivity did not change throughout treatment. In group E2 the sensitivity to the action of insulin decreased significantly in a gradual fashion between days 6 and 16; in group $\mathrm{E}$ we found that the insulin sensitivity remained without significant change during the first 11 days of treatment and decreased significantly between days 11 and 16 . In addition, we must point out that insulin sensitivity was always greater in the untreated group than in group E2, but these differences are significant only at day 11 of the experiment. These results demonstrate that group $\mathrm{E}$ was significantly more sensitive to the action of insulin than the other groups, and that this group was less sensitive at the end of hormonal treatment (day 16) than in the early period of hormonal treatment (days 6 and 11).
Table 1 shows the values of fasting blood glucose and fasting insulin plasma concentrations before and after clamp experiments. Fasting blood glucose concentrations were observed to be similar between groups and between days of the experimental period.

In the untreated group, the serum concentrations of insulin before the clamp study increased significantly throughout the experiment, whereas groups E and E2 had a similar insulin concentration profile, and in both groups this parameter decreased significantly between days 6 and 11 and increased significantly between days 11 and 16. In contrast, group E2 had significantly greater insulin concentrations than the others on any day of treatment.

After clamp experiments, the insulin plasma concentrations increased significantly throughout the experiment in the untreated group, whereas in group $\mathrm{E}$ this parameter decreased significantly throughout the treatment. In group E2, the plasma concentrations of insulin after the clamp decreased between days 6 and 11 and increased between days 11 and 16. At day 6 of treatment, the insulin concentrations after the clamp were significantly greater in group E than in the other groups, whereas at days 11 and 16 this parameter was significantly greater in the untreated group than in the other groups.

An initial Northern blot analysis of IRS-1 mRNA revealed, in agreement with the findings of Araki et al. (1995), a low abundance of IRS-1 mRNA in the tissues studied, so that quantification was not possible. Therefore, semiquantitative RT-PCR was performed to determine the level of expression of the IRS-1 gene (Fig. 3).

The hepatic IRS-1 mRNA levels (Fig. 3a) were significantly lower in group E2 than in the other groups at days 11 and 16 of treatment. The changes in this parameter through the experimental period were similar in the oestradiol-treated groups between days 11 and 16, when mRNA for IRS-1 decreased significantly. However, there were significant increases between days 6 and 11 in group E, but no changes in group E2. In the untreated group, the IRS-1 mRNA increased significantly throughout the experimental period.

In skeletal muscle (Fig. 3b), changes in the IRS-1 mRNA levels were not found at either the intra- or intergroup level.

In adipose tissue (Fig. 3c), the mRNA levels of IRS-1 were significantly greater in group $\mathrm{E}$ than in the other groups at day 6 of treatment, whereas at days 11 and 16 group E2 exhibited lower IRS-1 mRNA levels than the other groups. In contrast, in group $\mathrm{E}$ there were no significant changes throughout treatment, whereas in group E2 these mRNA levels showed significant decreases between days 11 and 16. In the untreated group, the levels of IRS-1 mRNA increased significantly throughout the experimental treatment.

Figure 4 shows a representative experiment in which solubilized liver, skeletal muscle and adipose tissue material were subjected to immunoprecipitation using 
(a)

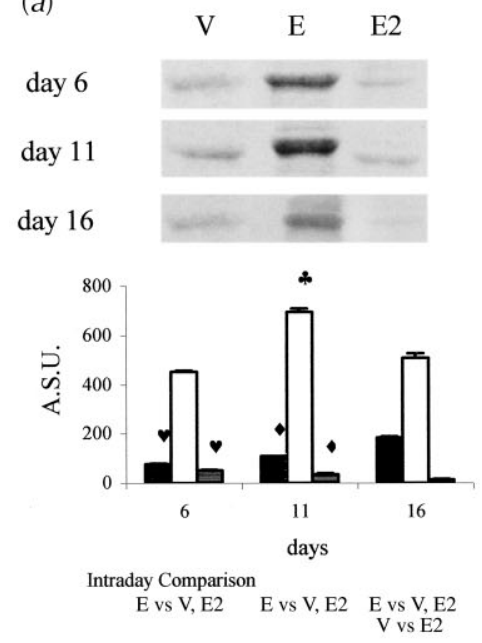

(b)
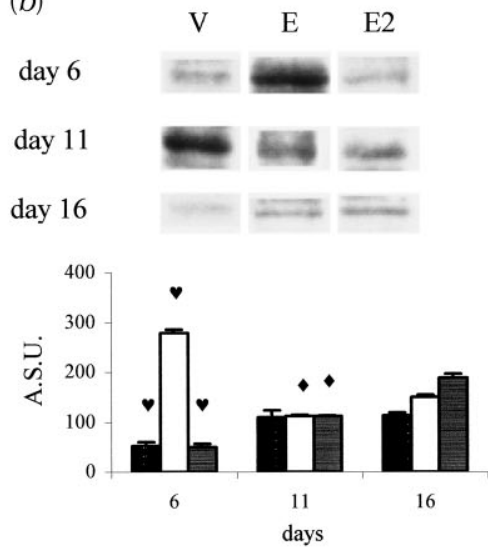

Intraday Comparison

$$
\begin{array}{ll}
\text { Evs V, E2 } & \text { E2 vs V, E } \\
& \text { V vs E }
\end{array}
$$

(C)

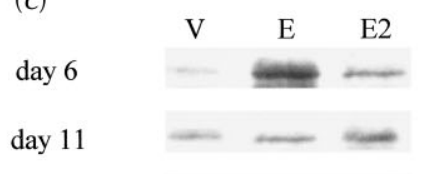

day 16

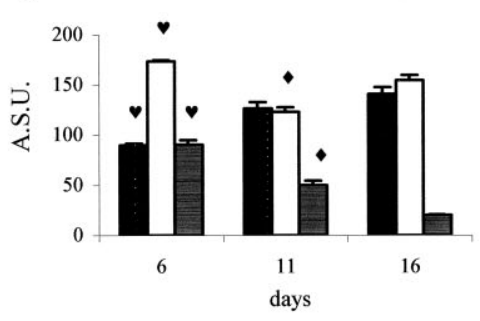

Intraday Comparison Evs V, E2 E2 vs V, E E2 vs V, E
V E E2
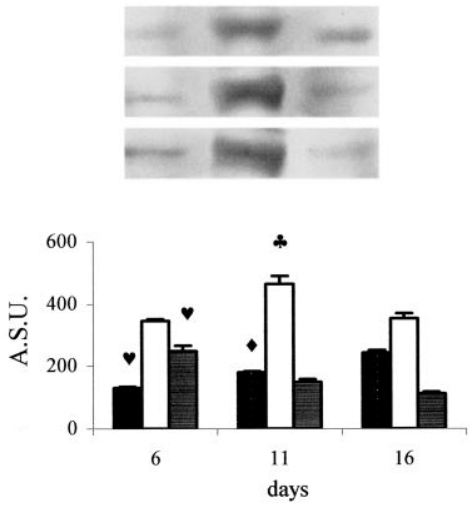

Intraday Comparison

$$
\begin{array}{lll}
\text { Vvs E, E2 } & \text { Evs V, E2 } & \text { V vs E, E2 } \\
\text { Evs E2 } & & \text { Evs E2 }
\end{array}
$$
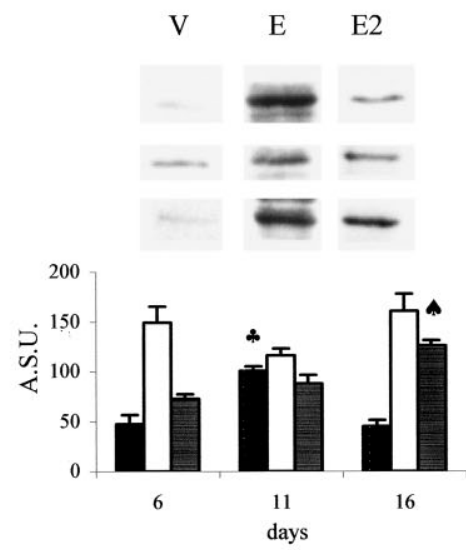

Intraday Comparison

Evs V, E2 Evs V, E2 V vs E, E2
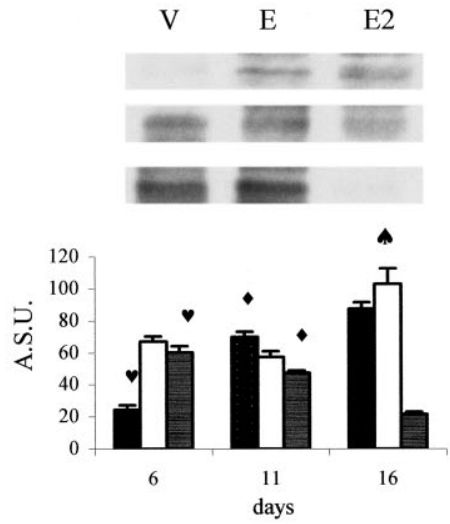

Intraday Comparison V vs E, E2 V vs E, E2 E2 vs V, E 
an anti-IRS-1 antibody. After SDS-PAGE and electrotransfer, nitrocellulose membranes were incubated in the presence of anti-phosphotyrosine antibody. ECL detection showed, in the materials immunoprecipitated, one band of $185 \mathrm{kDa}$ corresponding to the IRS-1. Later, the membranes were stripped and incubated in the presence of anti-IRS-1 antibody.

In liver, group E showed significantly greater IRS-1 levels than group E2 and the untreated group at any day of treatment (Fig. 4aI). Over the period of treatment, hepatic IRS-1 levels increased significantly in group E between days 6 and 11 and decreased between days 11 and 16. In group E2, the amount of IRS-1 decreased significantly throughout the period of hormonal treatment, whereas in the untreated group the IRS-1 levels increased significantly with the duration of treatment. The phosphorylation of IRS-1 in liver (Fig. 4aII) had a pattern similar to that of the amount of IRS-1.

At day 6 of treatment in skeletal muscle (Fig. 4bI), group E showed significantly greater concentrations of IRS-1 than the other groups; at day 11 no differences were found in these concentrations, and at day 16 group E2 showed a significantly greater amount of IRS-1 than the untreated group and group E. In group E, the duration of treatment was associated with a significant decrease in IRS-1 concentrations between days 6 and 11, whereas between days 11 and 16 these concentrations increased significantly. The amount of IRS-1 in group E2 increased significantly throughout the hormonal treatment, and in the untreated group the IRS-1 concentrations increased significantly between days 6 and 11. In contrast, the phosphorylation of IRS-1 in skeletal muscle (Fig. 4bII) showed a similar profile in group E2, increased significantly between days 6 and 11 and decreased between days 11 and 16 in the untreated group, and exhibited no significant changes in group E.

The amount of IRS-1 in adipose tissue (Fig. 4cI) was significantly greater in group $\mathrm{E}$ than in the other groups at day 6 of treatment, whereas at days 11 and 16 this amount was significantly lower in group E2 than in the other groups. Over the period of hormonal treatment, group E exhibited a significant decrease in IRS-1 concentrations between days 6 and 11, whereas these concentrations increased significantly between days 11 and 16 . In group $\mathrm{E} 2$, the duration of treatment was associated with a significant decrease in IRS-1 concentrations, whereas in the untreated group there was a significant increase throughout the experiment. In contrast, phosphorylation of IRS-1 in adipose tissue (Fig. 4cII) increased significantly throughout the treatment period in the untreated group, but decreased in group E2. In group E, IRS-1 phosphorylation increased significantly between days 11 and 16 .

\section{Discussion}

Several lines of evidence have revealed an association between female sex steroids and insulin sensitivity (Kumagai et al. 1993, Polderman et al. 1994). In addition, several clinical reports have shown that artificially or naturally increased oestradiol concentrations are linked to changes in insulin sensitivity (Cagnacci et al. 1992, Godsland 1996, Rincón et al. 1996, Colacurci et al. 1998, Karjalainen et al. 2001). In this study, we have investigated whether oestradiol had any effects on insulin sensitivity in ovariectomized rats treated with this steroid. We chose two different doses of $17 \beta$-oestradiol - a physiological dose (group E) that promotes gestational oestradiol concentrations (González et al. 2000) and a pharmacological dose (group E2) - and examined insulin sensitivity using a hyperinsulinaemic-euglycaemic clamp method (González et al. 2000). In group E, we were able to see a decrease in insulin sensitivity at the end of treatment (between days 11 and 16) (Fig. 2c), which reflects the events of late gestation. In this way, we and others (Herrera et al. 1991, González et al. 1998, 2002a) have shown that there is a decrease in insulin sensitivity at late gestation, and this insulin resistance at the end of gestation determines a competitive advantage for the foetuses because uterine glucose uptake and placental glucose transport are relatively unaffected by maternal insulin (Rankin et al. 1986). Present results on the clamp in group E (Fig. 2c) suggest that the gestational dose of $17 \beta$-oestradiol seems to be able to reproduce the changes in insulin sensitivity that are induced by pregnancy (González et al. 1998, 2002b).

However, the results in group E2 show that pharmacological doses of $17 \beta$-oestradiol promote the development of insulin resistance from the early treatment period (Fig. $2 c$ ). These findings are in agreement with those of most of the authors who have reported that high doses of oestradiol are associated with insulin resistance (Barret-Connor \& Laakso 1990, Troisi et al. 2000). Moreover, according to our findings in the oestradiol-treated groups (E and E2), the effects of this steroid on insulin sensitivity seem to be dose-dependent. If we analyse the changes in insulin sensitivity in oestradiol-treated groups, we can see that

\footnotetext{
Figure 4 Representative experiments for measurement of IRS-1 protein concentrations and phosphorylation in (a) liver, (b) skeletal muscle and (c) adipose tissue in control rats (solid bars, V) and oestradiol-treated rats (open bars, group E; shaded bars, group E2). The proteins were isolated with lysis buffer, as described in Methods; after centrifugation, aliquots of the supernatant were immunoprecipitated with anti-IRS-1 antibody and immunoblotted with anti-phosphotyrosine antibody. Later, the membranes were incubated with stripping buffer and immunoblotted with anti-IRS-1 antibody. Data are expressed as means \pm S.E.M. A.S.U., arbitrary scanning units. Significant differences between treatment groups are listed for each experimental time point (intraday comparison). Within the treatment groups, the following

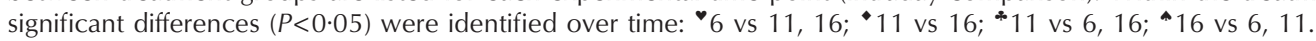


there is a difference in insulin sensitivity between group E (lower dose) and group E2 (higher dose), in line with the findings in another study (Linheim et al. 1993) and confirming our above hypothesis. However, in the ovariectomized control group, there was a progressive impairment in insulin sensitivity throughout treatment. These observations are in agreement with those of others (Kumagai et al. 1993, González et al. 2000) who have shown that the absence of female sex steroids results in a decreased insulin sensitivity.

We also investigated whether the molecular mechanism underlying these changes in insulin sensitivity is related to IRS-1. In the past few years, considerable advances in knowledge have been made concerning the insulin intracellular signalling pathways, and IRS-1 represents the epicentre for the majority of insulin receptor downstream signalling events involved in the actions of insulin (White 1998). In group $\mathrm{E}$, we found a decrease in insulin sensitivity between days 11 and 16 similar to that in late gestation (Fig. 2c). However, when we analysed the changes in IRS-1 expression we did not find a straightforward relationship between this parameter and the changes in insulin sensitivity (Fig. 3): when the insulin sensitivity decreased between days 11 and 16 of treatment, the amount of IRS-1 and its phosphorylation significantly increased in peripheral tissues (skeletal muscle and adipose tissue) (Fig. $4 b$ and $c$ ) and decreased in the liver (Fig. 4a). These results do not seem to be in line with those of a previous study in which we showed that insulin receptor performance in rats treated with a gestational dose of $17 \beta$-oestradiol was related to changes in insulin sensitivity (González et al. 2002b) in a tissue-specific manner. In this context, we think that the regulation of IRS- 1 by $17 \beta-$ oestradiol could be mediated in a manner different from that of the insulin receptor, because IRS-1 has a pivotal role in several pathways such as leptin (Szanto \& Kahn 2000), growth hormone (GH) (Liang et al. 2000) and prolactin (Berlanga et al. 1997). Although the biological endpoints of these endocrine pathways are quite different, there are several overlapping points during the intermediate steps comprising the signal transduction machinery, which involves considerable intracellular compartmentalization. In the past few years several reports (Clark et al. 1998, Whitehead et al. 2000) have shown that IRS-1 could be localized in two different pools: the cytoskeletal component and the cytosol. In this respect, the mode of IRS-1 recruitment is quite different between insulin and other hormones: insulin mediates IRS-1 phosphorylation through the tyrosine kinase activity of a membrane insulin receptor (Sun et al. 1992, White \& Kahn 1994, Virkamaki et al. 1999), whereas the other hormones use a family of cytoplasmic tyrosine kinases termed Janus kinases (Berlanga et al. 1997, Liang et al. 2000, Szanto \& Kahn 2000).

It has been argued that the cytoskeletal component represents the functional pool of IRS-1 for the insulin signalling pathway, because it provides a platform for locating IRS-1 proteins within the proximity of the membrane insulin receptor. Olson et al. (2001) recently proposed that the insulin signalling cascade leading specifically to glucose transporter 4 vesicle recruitment is located in microtubules of the cytoskeleton and, in agreement with these authors, it has been reported (Clark et al. 1998) that there is a fraction of PI3K that is also located on the cytoskeleton. The microtubule network, which forms the cytoskeletal scaffold, may ensure the correct juxtaposition of different enzymes in the insulin signalling cascade, enabling them to interact in a very robust manner. Moreover, it has been reported that the inappropriate release of the IRS-1 proteins to the cytosol causes insulin resistance (Clark et al. 2000). Thus it has been shown that treatment with oestradiol determines a decrease in insulin sensitivity through a mechanism that involves a release of IRS-1 proteins from the intracellular cytoskeleton (Collison et al. 2001). With the clamp experiments, insulin resistance means that there is a low glucose uptake in response to insulin stimulation and that IRS-1 has effects on glucose transport only when it is recruited by the insulin receptor. Taking these data together with our own findings, we postulated that the decrease in insulin sensitivity in group E between days 11 and 16 of treatment could be related to a release of IRS-1 protein from the cytoskeletal scaffold, where it is able to interact with the insulin receptor and pass to the cytosol, where it could be recruited by another hormonal signalling pathway. However, our results on IRS-1 seem not to confirm those of Saad et al. (1997), who reported a decrease in the expression of IRS-1 in skeletal muscle during late pregnancy. We consider that these differences could have various explanations. In our experimental design, we ensured that no other gestational hormones were present that could regulate the expression of IRS-1, because this protein could be implicated in its own intracellular signalling pathway. Moreover, the experiments by Saad's group were relevant to the end of gestation (day 20-21), whereas in our oestradiol treatment we simulated gestational plasma concentrations of oestradiol up to day 16 of gestation (Fig. 2a).

In the clamp experiments, the E2 and the untreated groups were similar in that insulin sensitivity decreased throughout the experimental period (Fig. 2c). However, analysis of the results for IRS-1 revealed a different pattern: in liver and adipose tissue, IRS-1 mRNA, protein and phosphorylation decreased significantly in group E2 throughout the experiment, whereas in the untreated group they increased (Figs 3 and 4). We think that insulin resistance in the untreated group and that in group E2 have different molecular mechanisms. In group E2, the development of insulin resistance throughout the experimental period could be related to a decrease in the expression of IRS-1 in liver and adipose tissue, in agreement with the findings of other authors (Carvalho et al. 
1996, 1999). This is in agreement with previous work in which we demonstrated that a pharmacological dose of $17 \beta$-oestradiol mediates a significant decrease in insulin receptor (González et al. 2002b). It seems that pharmacological doses of $17 \beta$-oestradiol determine insulin resistance through decreases in the first steps of the insulin signalling system. We believe that the effect on the expression of insulin receptor and the IRS-1 gene could be due to the possible existence of the consensus response elements to oestradiol in the insulin receptor and IRS-1 gene promoter. Probably, the high plasma concentration of oestradiol in group E2 was determining the binding of many complexes of oestradiol receptor-oestradiol to the insulin receptor and IRS-1 promoter, and this fact could determine the linking of these complexes or the displacement of the other transcription factors such as lactogenic hormones, $\mathrm{GH}$, etc. We are currently testing this hypothesis. It is also possible that a pharmacological dose of $17 \beta$-oestradiol could be implicated in a release of IRS- 1 proteins from the cytoskeleton to the cytosol, which would increase the development of insulin resistance.

In contrast, in the untreated group there was no relationship between the development of insulin resistance and changes in IRS-1 and insulin receptor expression (González et al. 2002b). Present findings in the untreated group are in agreement with the hypothesis of oestradiol receptor-oestradiol complexes mentioned above. Oestradiol seems to be able to mediate changes in insulin sensitivity, and so the absence of oestradiol in the untreated group determined the absence of the oestradiol receptor-oestradiol complexes, and regulation of insulin receptor and IRS-1 gene expression was not related to changes in insulin sensitivity in the untreated group. However, we cannot exclude the possibility that the absence of female sex steroids could be implicated in changes in the intracellular distribution of IRS-1, and this could be related to a decrease in insulin sensitivity. In this respect, the results for body weight also show different metabolic performance in the untreated group and group $\mathrm{E} 2$, the weight gain in the untreated group being significantly greater than that in group E2 (Fig. 2b). Many studies have demonstrated that the absence of female sex hormones determines an increase in body weight in rats (Kumagai et al. 1993, González et al. 2000), monkeys (Wagner et al. 1998) and humans (Tremollieres et al. 1996), and this increase could be prevented by oestradiol treatment (Fineberg 2000, González et al. 2000). However, this effect of $17 \beta$-oestradiol seems to be independent of the dose, because we did not find differences in body weight gain between groups E and E2. We did not measure plasma leptin concentrations, but the mechanism responsible for these changes in body weight is likely to be related to this hormone. Leptin is the main regulator of feeding behaviour (Szanto \& Kahn 2000). It has been reported that loss of ovarian function determines an increase in food intake (Wade 1975), and that

www.endocrinology.org ovariectomy-induced weight gain is caused by a decrease in leptin concentration (Chu et al. 1999), which could be prevented by $17 \beta$-oestradiol treatment (Kristensen et al. 1999). In this context, it has been proposed that leptin and insulin signalling networks may be connected at the level of IRS-1 (Szanto \& Kahn 2000), but most evidence seems to suggest that there is a tissue-specific interaction between leptin and insulin that is quite variable. However, the lipolytic effects of $17 \beta$-oestradiol in controlling adipose lipoprotein lipase cannot be disregarded (Jensen et al. 1994).

In summary, our results show that a gestational dose of $17 \beta$-oestradiol (group E) is able to reproduce the changes in insulin sensitivity during pregnancy. However, the decrease in insulin sensitivity between days 11 and 16 is not associated with a decrease in IRS-1 expression. We believe that this decrease in insulin sensitivity could be related to a modification in the intracellular distribution of IRS-1. Conversely, a pharmacological dose of $17 \beta$-oestradiol mediated the development of insulin resistance through a decrease in IRS-1 expression and protein phosphorylation in liver and adipose tissue. However, it is also possible that this could be related to a release of IRS proteins to the cytoskeletal scaffold. Moreover, the insulin resistance produced by the absence of female sex steroids is not related to changes in IRS-1 expression.

\section{Acknowledgements}

This study was supported by grants from the University of Oviedo (NP-98-516-3 and AYP-02-518), the Dirección Regional de Universidades e Investigación del Principado de Asturias as part of the II Plan Regional de Investigación (PP-SAL-98-02).

\section{References}

Andersson B, Mattsson LA, Hahn L, Marin P, Lapidus L, Holm G, Bengtsson BA \& Björntorp P 1997 Oestrogen replacement therapy decreases hyperandrogenicity and improves glucose homeostasis and plasma lipids in post-menopausal women with non-insulin diabetes mellitus. Journal of Clinical Endocrinology and Metabolism 82 638-643.

Araki E, Haag B, Matsuda K, Schichiri M \& Kahn CR 1995 Characterization and regulation of the mouse insulin receptor substrate gene promoter. Molecular Endocrinology 9 1367-1369.

Barret-Connor E \& Laakso M 1990 Ischaemic heart disease risk in post-menopausal women: effect of estrogen on glucose and insulin levels. Arterioesclerosis 10 531-534.

Beato M 1989 Gene regulation by steroid hormones. Cell 56 335-344. Berlanga JJ, Gualillo O, Buteau H, Applanat M, Kelly PA \& Edery M 1997 Prolactin activates tyrosyl phosphorylation of insulin receptor substrate 1 and phosphatidylinositol-3-OH kinase. Journal of Biological Chemistry 272 2050-2052. 
Bradford MM 1976 A rapid and sensitive method for the quantitation of microgram quantities utilizing the principle of protein dye binding. Analytical Biochemistry 72 248-254.

Brussard HE, Gevers Leuven JA, Frolich M, Kluft C \& Krans HMJ 1997 Short-term oestrogen replacement therapy improves insulin resistance, lipids and fibrinolysis in postmenopausal women with NIDDM. Diabetologia 40 843-849.

Cagnacci A, Soldani R, Carriero PL, Paoletti AM, Fioretti P \& Melis GB 1992 Effects of low doses of 17- $\beta$-estradiol on carbohydrate metabolism in postmenopausal women. Journal of Clinical Endocrinology and Metabolism 74 1396-1400.

Carvalho CRO, Brenelli SL, Silva AC, Nunes ALB, Velloso LA \& Saad MJ 1996 Effect of aging on insulin receptor, insulin receptor substrate-1 and phosphatidylinositol 3-kinase in liver and muscle of rats. Endocrinology 137 151-159.

Carvalho E, Jansson PA, Axelsen M, Eriksson JW, Huang X, Groop L, Rondinone C, Sjostrom L \& Smith U 1999 Low cellular IRS 1 gene and protein expression predict insulin resistance and NIDDM. FASEB Journal 13 2173-2178.

Chomczynski P \& Sacchi N 1987 Single-step method of RNA isolation by acid guanidinium thiocyanate-phenol-chloroform extraction. Analytical Biochemistry 162 156-159.

Chu SC, Chou YC, Liu JY, Chen CH, Shyu JC \& Chou FP 1999 Fluctuation of serum lipids after ovariectomy and the influence of estrogen supplement. Life Sciences 64 2299-2306.

Clark SF, Martin S, Carozzi AJ, Hill MM \& James DE 1998 Intracellular localization of phosphatidylinositide 3-kinase and insulin receptor substrate-1 in adipocytes: potential involvement of a membrane skeleton. Journal of Cell Biology 140 1211-1225.

Clark S, Molero JC \& James DE 2000 Release of insulin receptor substrate 1 proteins from an intracellular complex coincides with the development of insulin resistance. Journal of Biological Chemistry 275 3819-1826.

Colacurci N, Zarcone R, Mollo A, Russo G, Passaro M, De Seta L \& De Franciscis P 1998 Effect of hormone replacement therapy on glucose metabolism. Pannminerva Medicine 40 18-21.

Collison M, Campbell IW, Salt IP, Dominiczak AF, Connel JMC \& Gould GW 2001 Sex hormones induce insulin resistance in 3Y3-L1 adipocytes by reducing cellular content of IRS-1 protein. Diabetologia 43 1374-1380.

DeFronzo RA \& Ferrannini MD 1991 Insulin resistance. A multifaceted syndrome responsible for NIDDM, obesity, hypertension, dyslipidemia and atherosclerotic cardiovascular disease. Diabetes Care 14 173-194.

Dunaif A, Segal KR, Shelley DR, Green G, Dobrjansky A \& Licholai T 1992 Evidence for distinctive bad intrinsic defects in insulin action in polycystic ovary syndrome. Diabetes 41 1257-1266.

Fagan TC \& Deedwania PC 1998 The cardiovascular dysmetabolic syndrome. American Journal of Medicine 105 775-825.

Ferrara A, Karter AJ, Ackerson LM, Liu JY \& Selby JV 2001 Hormone replacement therapy is associated with better glycemic control in women with type 2 diabetes: the Northern California Kaiser Permanent Diabetes Registry. Diabetes Care 24 1144-1150.

Fineberg SE 2000 Glycaemic control and hormone replacement therapy. Implications of the postmenopausal estrogen/progestogen interventions (PEPI) study. Drugs and Aging 17 453-461.

Godsland IF 1996 The influence of female sex steroids on glucose metabolism and insulin action. Journal of Internal Medicine Supplement 738 1-60.

Goldfine ID 1987 The insulin receptor: molecular biology and transmembrane signalling. Endocrine Reviews 8 235-255.

González C, Díaz F, Fernández S \& Patterson AM 1997 Role of $17-\beta$-estradiol and progesterone on glucose homeostasis: effects of food restriction $(50 \%)$ in pregnant and non-pregnant rats. Journal of Endocrinological Investigation 20 397-403.

González C, Díaz F, Fernández S \& Patterson AM 1998 Pregnancy in rats and food restriction (50\%): insulin response in relation to serum lipids and lipoprotein levels. Nutrition Research 18 1235-1244.
González C, Alonso A, Alvarez N, Diaz F, Martinez M, Fernández S \& Patterson AM 2000 Role of $17 \beta$-estradiol and/or progesterone on insulin sensitivity in the rat: implications during pregnancy. Journal of Endocrinology 166 283-291.

González C, Alonso A, Balbín M, Fernández S \& Patterson AM $2002 a$ Effects of pregnancy on insulin receptor in liver, skeletal muscle and adipose tissue of rats. Gynecological Endocrinology 16 193-205.

González C, Alonso A, Grueso NA, Esteban MM, Fernández S \& Patterson AM $2002 b$ Effects of treatment with different doses of $17-\beta$-estradiol on the insulin receptor. Life Science 70 1621-1630.

Gosbell AD, Favilla I, Baxter KM \& Jablonski P 2000 Insulin receptor and insulin receptor substrate-1 in rat retinae. Clinical and Experimental Ophthalmology 28 212-215.

Herrera E, Lasunción MA, Palacín M, Zorzano A \& Bonet B 1991 Intermediary metabolism in pregnancy. First theme of the Freinkel Era. Diabetes 40 83-88.

Huang Z, Bodkin NL, Ortmeyer HK, Zenilman ME, Webster NJ, Hansen BC \& Shuldiner AR 1996 Altered insulin receptor messenger ribonucleic acid splicing in liver is associated with deterioration of glucose tolerance in the spontaneously obese and diabetic rhesus monkey: analysis of controversy between monkey and human studies. Journal of Clinical Endocrinology and Metabolism 81 1152-1156.

Jensen MD, Martin ML, Cryer PE \& Roust LR 1994 Effects of estrogen on free acid metabolism in humans. American Journal of Physiology 266 E914-E920.

Kaaks R \& Lukanova A 2001 Energy balance and cancer: the role of insulin and insulin-like growth factor-I. Proceedings of the Nutrition Society 60 91-106.

Karjalainen A, Paassilta M, Heikkinen J, Bäckström A-C, Savolainen M \& Kesäniemi YA 2001 Effects of peroral and transdermal oestrogen replacement therapy on glucose and insulin metabolism. Clinical Endocrinology 54 165-173.

Krauss RM, Perlman JA, Ray R \& Petitti D 1988 Effect of estrogen dose and smoking on lipid and lipoprotein levels in postmenopausal women. American Journal of Obstetrics and Gynecology $\mathbf{1 5 8}$ 1606-1611.

Kristensen K, Pedersen SB \& Richelsen B 1999 Regulation of leptin by steroid hormones in rat adipose tissue. Biochemical and Biophysical Research Communications 259 624-630.

Kumagai S, Holmang A \& Björntorp P 1993 The effects of oestrogen and progesterone on insulin sensitivity in female rats. Acta Physiologica Scandinavica 149 91-97.

Lee AV, Jackson JG, Gooch JL, Hilsenbeck SG, Coronado-Heinsohn E, Osborne CK \& Yee D 1999 Enhancement of insulin-like growth factor signalling in human breast cancer: estrogen regulation of insulin-receptor substrate-1 expression in vitro and in vivo. Molecular Endocrinology 13 787-796.

Liang L, Jiang J \& Frank SJ 2000 Insulin receptor-substrate1-mediated enhancement of growth hormone-induced mitogen activated protein kinase activation. Endocrinology 141 3328-3336.

Lindheim SR, Presser SC, Ditkoff EC, Vijod MA, Stanczyk FZ \& Lobo RA 1993 A possible bimodal effect of estrogen on insulin sensitivity in postmenopausal women and the attenuating effect of added progestin. Fertility and Sterility 60 664-667.

Lindheim SR, Duffy DM, Kojima TK, Vijoid MA, Stanczyk FZ \& Lobo RA 1994 The route of administration influences the effect of estrogen on insulin sensitivity in postmenopausal women. Fertility and Sterility 62 1176-1180.

Molloy CA, May F \& Westley BR 2000 Insulin receptor substrate-1 expression is regulated by estrogen in the MCF-7 human breast cancer cell line. Journal of Biological Chemistry 275 12565-12571.

Olson AL, Trumbly AR \& Gibson GV 2001 Insulin-mediated GLUT4 translocation is dependent on the microtubule network. Journal of Biological Chemistry 276 10706-10714. 
Polderman KH, Gooren LJ, Asscheman H, Bakker A \& Heine RJ 1994 Induction of insulin resistance by androgens and estrogens. Journal of Clinical Endocrinology and Metabolism 79 265-271.

Rankin JHG, Jodarski G \& Shanahan MR 1986 Maternal insulin and placental 3-O-methyl glucose transport. Journal of Developmental Physiology 8 247-253.

Reaven GM 1993 Role of insulin resistance in human disease (syndrome X): an expanded definition. Annual Review of Medicine 44 121-131.

Rincón J, Holmäng A, Odegaard Wahlström E, Lönnroth P, Björntorp P, Zierath JR \& Wallberg-Henriksson H 1996 Mechanism behind insulin resistance in rat skeletal muscle after oophorectomy and additional testosterone treatment. Diabetes $\mathbf{4 5}$ 615-621.

Saad MJA, Maeda L, Brenelli SL, Carvalho CRO, Paiva RS \& Velloso LA 1997 Defects in insulin signal transduction in liver and in muscle of pregnant rats. Diabetologia 40 179-186.

Sattar N 1998 Hormone replacement therapy in type 2 diabetes mellitus: a cardiovascular perspective. Diabetic Medicine 15 631-633.

Sun XJ, Miralpeix M, Myers MG Jr, Glasheen EM, Backer JM, Kahn CR \& White MF 1992 Expression and function of IRS-1 in insulin signal transmission. Journal of Biological Chemistry 267 22622-22672.

Szanto I \& Kahn CR 2000 Selective interactions between leptin and insulin signalling pathways in a hepatic cell line. PNAS 97 2355-2360.

Towbin H, Staehlin J \& Gordon J 1979 Electrophoretic transfer of proteins from polyacrilamide gels to nitrocellulose sheets. Procedure and some applications. PNAS 76 4350-4353.

Tremollieres FA, Pouilles JM \& Ribot CA 1996 Relative influence of age and menopause on total and regional body composition changes in postmenopausal women. American Journal of Obstetrics and Gynecology 175 1594-1600.
Troisi RJ, Cowie CC \& Harris MI 2000 Oral contraceptive use and glucose metabolism in a national sample of women in the United States. American Journal of Obstetrics and Gynecology 183 389-395.

Virkamäki A, Ueki K \& Kahn CR 1999 Protein-protein interactions in insulin signalling and the molecular mechanism of insulin resistance. Journal of Clinical Investigation 103 931-943.

Wade GN 1975 Some effects of ovarian sex hormones on food intake and body weight in female rats. Journal of Comparative Physiology and Psychology 88 1277-1283.

Wagner JC, Thomas MJ, Williams JK, Zhang L, Greaves KA \& Cefalu WT 1998 Insulin sensitivity and cardiovascular risk factors in ovariectomized monkeys with estradiol alone or combined nomegestrol acetate. Journal of Clinical Endocrinology Metabolism 83 896-901.

Waters SB \& Pessin JE 1996 Insulin receptor substrate 1 and 2 (IRS1 and IRS2): what a tangled web we weave. Trends in Cell Biology 6 $1-4$.

White MF 1998 The IRS-signalling system: a network of docking proteins that mediate insulin action. Molecular and Cellular Biochemistry 182 3-11.

White MF \& Kahn CR 1994 The insulin signalling system. Journal of Biological Chemistry 269 1-4.

Whitehead JP, Clark SF, Urso B \& James DE 2000 Signalling through the insulin receptor. Current Opinion in Cell Biology 12 222-228.

Writing Group for the PEPI Trial 1995 Effects of estrogen or estrogen/progesten regimens on heart disease risk factors in postmenopausal women: the postmenopausal estrogen/progesten interventions (PEPI) trial. Journal of the American Medical Association 273 199-208.

Received in final form 26 September 2002 Accepted 15 November 2002 